\title{
ARTICLE
}

\section{Saving the forgotten kingdom in Malta}

\section{Lewis M}

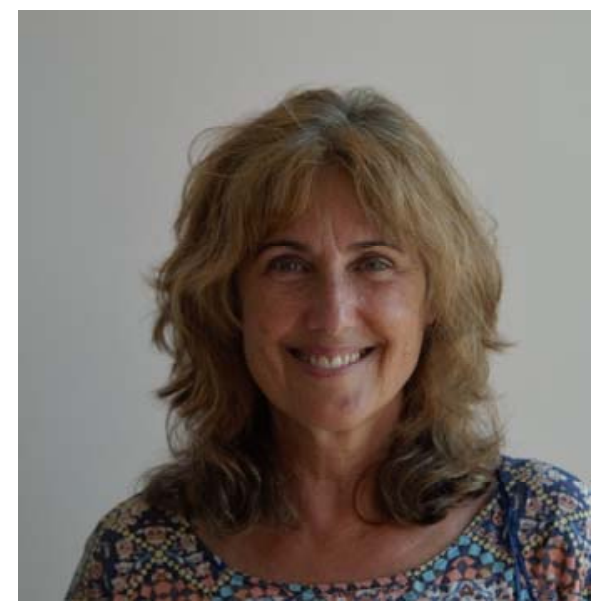

Malta Mycological Association, Hyfen Court No 19, Triq Awwista, Xemxija, St Paul's Bay SPB 2040, Malta

Lewis M 2018 - Saving the forgotten kingdom in Malta. Microbial Biosystems 3(1), 74-83.

\begin{abstract}
Fungi are different from animals and plants. Since at least the 1970s, scientists have agreed that fungi belong in their own separate biological kingdom which is likely to contain far more species than the plant kingdom. Ecologically and economically, the Fungi Kingdom is of an immense value and is necessary for sustainable life on planet earth. There are six kingdom classifications of life - with Fungi classified as a kingdom of their own. Taxa of Kingdom Fungi are diverse, and as the second largest group of organisms - after insects, are distributed among numerous groups of living organisms. Technological advances in molecular research have enabled mycologists to discover and identify fungal taxa. It is estimated that as many as 1.5 million fungal species exist.

In Malta the public perception, biodiversity and conservation of fungi is very low with awareness being close to non-existent. A lot of education regarding the subject is urgently needed. Malta Mycological Association (MMA) was founded only recently (2014) in an effort to promote awareness, interest and conservation regarding the importance of fungi, their function in the ecological system along with the importance and benefits of their existence in our environment.

This work has to be considered as an important contribution to the nature conservation program in Malta. One important theme is the sustainable use of fungal resources, enforcement of legislations and conventions concerning the fungal diversity in different habitats in Malta. In addition to the urgency of environmental education, the application of appropriate protectedarea-management systems is also recommended. Given the importance of fungi to the biosphere
\end{abstract}


and the increasing interest in fungal conservation worldwide, addressing oversights and obstacles such as these is a crucial step towards effective protection and management of fungi.

Key words - Basidiomycota, biodiversity, conservation, fungi, MMA, Red-list

\section{Introduction}

Fungi are different from animals and plants. Since the 1970s, scientists have agreed that fungi belong in their own separate biological kingdom which is likely to contain far more species than the plant kingdom. Where plants produce and animals consume, fungi are the recyclers. Fungi are just as much threatened as animals and plants by climate change, habitat destruction, invasives, pollution, over-exploitation and even, in some cases, persecution. Habitats important for threatened fungi may be different from habitats important for threatened animals and plants (Abdel-Azeem and Salem 2017). Biodiversity can only be conserved if the well-being of fungi is given as much consideration as that of animals and plants: without fungi life on earth would be unsustainable. Fungi provide enormously important ecosystem services (e.g. soil fertility, mycorrhizas, crop protection, litter decomposition, checks and balances). The economic value of such services has been estimated as running to trillions of US dollars. Fungi are also a very important source of unusual chemicals of great value in industry and medicine. The yeast used to make bread is a fungus, and many pharmaceuticals such as antibiotics, statins and anti-cancer drugs are derived from fungi (Abdel-Azeem and Salem 2017).

Malta (Fig. 1) is the $10^{\text {th }}$ smallest island country with just $316 \mathrm{~km}^{2}$ of land area and a population of 475,000 , making it also one of the world's most densely populated countries (https://www.timesofmalta.com/articles/view/20180710/local/increase-in-malta-populationmore-than-15-times-that-of-the-eu.). It lies $97 \mathrm{~km}$ south of Sicily, Italy, $284 \mathrm{~km}$ east of Tunisia, $333 \mathrm{~km}$ north of Libya and $745 \mathrm{~km}$ west of Greece, $1520 \mathrm{~km}$ south west of Egypt. The archipelago consists of three inhabited islands: Malta $\left(246.5 \mathrm{~km}^{2}\right)$, Gozo $\left(65.8 \mathrm{~km}^{2}\right)$ and Comino $\left(2.9 \mathrm{~km}^{2}\right)$. These are composed of oligo-miocene sedimentary rock and along with Sicily are part of the African continental plate.

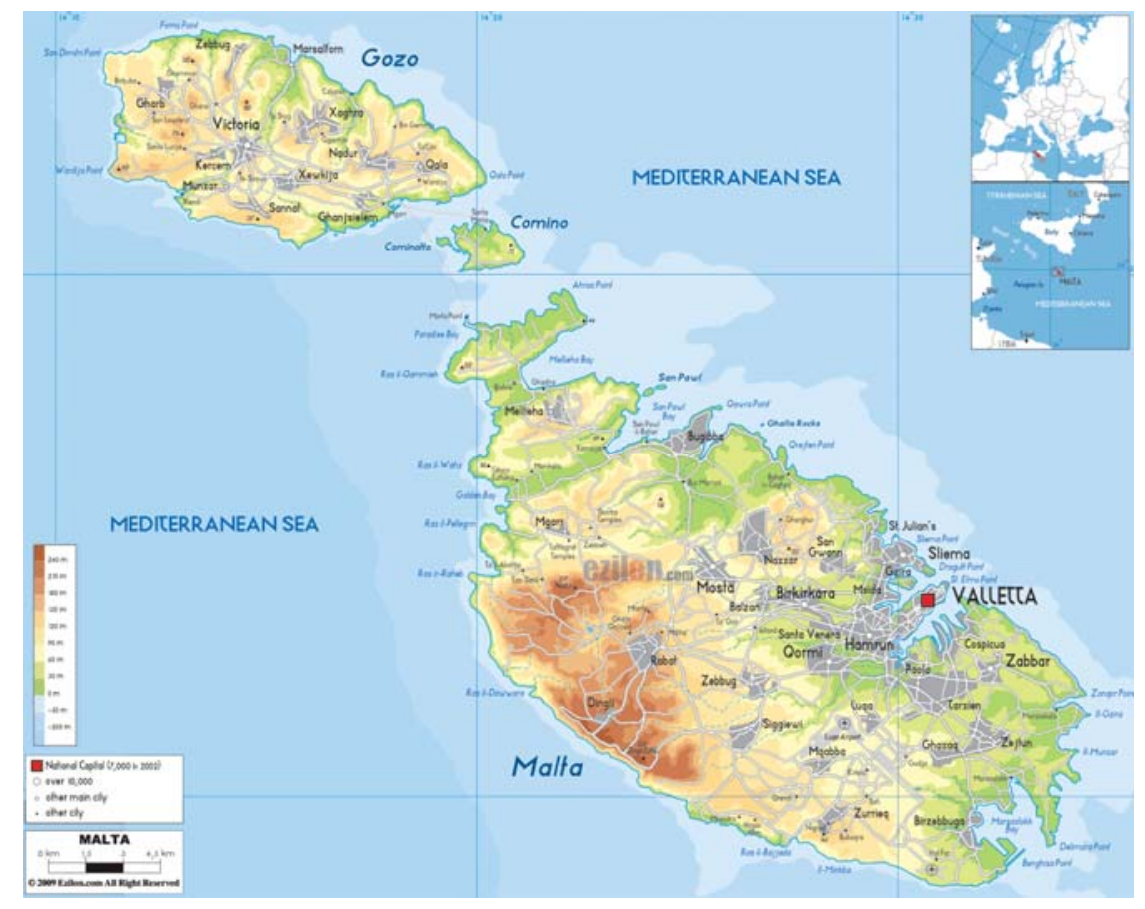

Fig. 1- Major biogeographical/bioclimatic regions of Malta. (https://www.ezilon.com/maps/europe/malta-physical-maps.html) 
The islands mainly consist of Garigue an ecosystem of low scattered, usually xerophytic and aromatic shrubs, Steppe vegetation that consist of grasslands, Rupestral communities mainly found on the southern and western slopes of the island, Maquis which is the dominant ecosystem. The only Woodland that remains today is the one located at Buskett, this has undergone a lot of destruction over the last few centuries in favour of agriculture. It is now a protected area by Malta Environment Protection Authority due to its rich fauna and flora with many nationally endangered, threatened and/or endemic species confined to this area throughout the whole country. Very limited research has been done by the department on the study of fungi.

In Malta, the main concern with fungi and lichens conservation lies with the loss of habitat and/or its modification, rather than their exploitation. Habitat conservation is hence deemed to be more effective towards fungi and lichen conservation and protection. According to the Habitats Directive paper two species were proposed for inclusion into Appendix II of the Bern Convention, Boletopsis grisea and Sarcosphaera coronaria both of which are confined to Buskett.

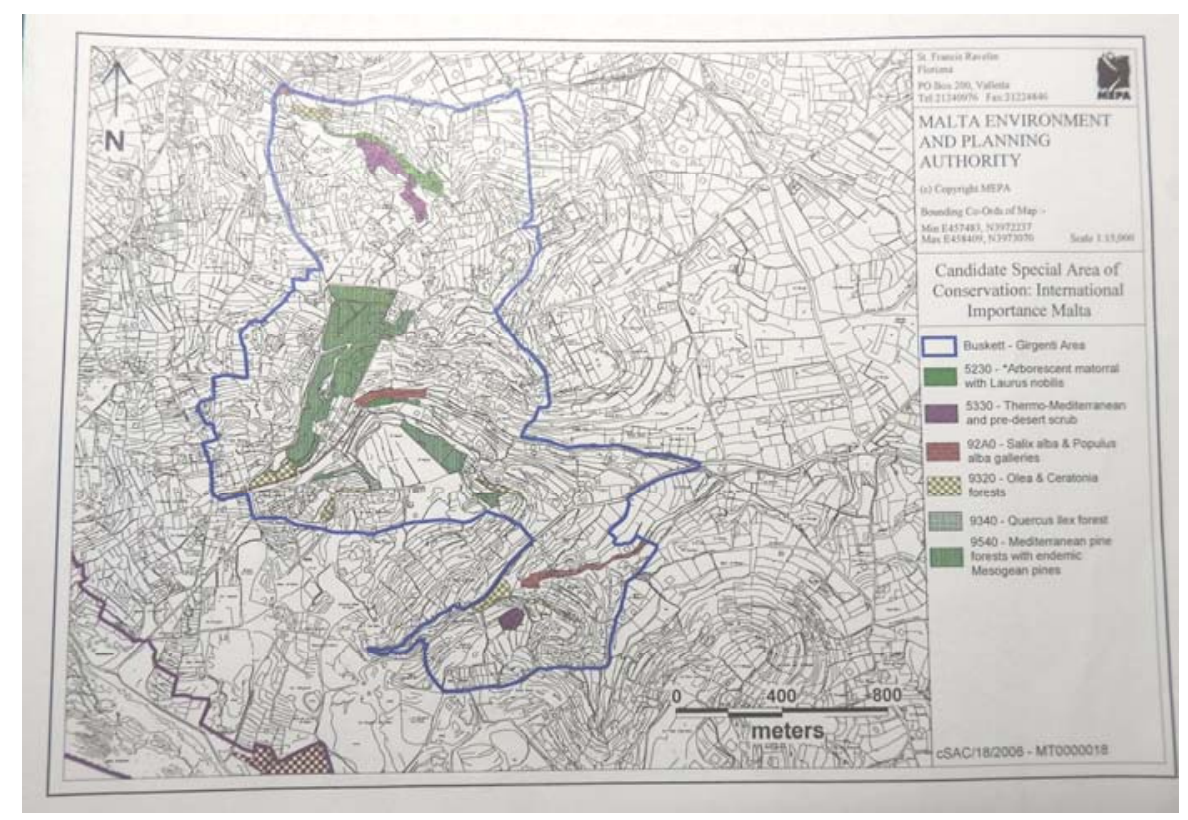

Fig. 2- Malta Environment and Planning Authority - Copyright of MEPA - Candidate Special Area of Conservation: International Importance Malta.

Most of the macrofungi (and protozoan fungal analogues (Myxomycetes)) reported from the Maltese Islands are essentially confined to protected areas, including most of the species listed in the official Red Data Book for the Maltese Islands (Schembri and Sultana 1989), published by the Department of Information. Fungi are mostly known from holm oak forest remnants, such as those at Il-Ballut (1/o Il-Wardija), Il-Ballut (1/o L Imgiebah), Ta' Baldu/Wied Hażrun and Il-Bosk, and from pine woodland, maquis and riparian woodland assemblages of the area of Il-Buskett and il-Girgenti, especially at Il-Buskett, Ghajn il-Kbira, Ta' Rapa, Il-Verdala and Wied il-Luq. Another important area is the carob-lentisk maquis at Wied Ghollieqa (1/o San Ġwann), as well as the various valley, pre-desert scrub and phrygana communities known from Wied Babu (1/o Iż-Żurrieq). Fungi are also known from garrigue communities, such as those at Ix-Xaghra tal-Borghom (L-Imtaћleb, 1/o Ir-Rabat).

Malta Mycological Association (MMA) was founded on the $20^{\text {th }}$ of October 2014 primarily as an informative page on Facebook (https://www.facebook.com/mycomalta/) to attract and shed the light on fungal interest on the island with regards to the importance of fungi. On the $28^{\text {th }}$ January 2015 a lecture was held at the Museum of Natural History in Mdina to explore and 
gather local interest and information on the study of mycology in Malta. MMA's main aim is to create awareness of the diversity of the fungal kingdom, along with promoting, protecting and conserving these substantial organisms.

A total of 63 species have been collected thus far by MMA, some of these still need to be properly identified. Given the size of the island and the continuous environmental stresses imposed, still a healthy variety of macrofungi can be found albeit a bit impossible at times.

Recently, in March 2017, Sustainability Design Collective (SDC) was established under whose umbrella Malta Mycological Association is pivotal. The purpose of this section of the organisation is to raise awareness about the importance of fungi in our daily lives. Mycology is a subject that is hardly touched upon on the island with only a few people interested. We seek collaboration with other mycological societies to assist us in holding local workshops and sharing their expertise to encourage understanding of their importance and impact on the environment.

In delivering the targets outlined in SDC, Malta Mycological Association is taking a lead in fungus conservation in Malta and will contribute significant progress to fill the gaps concerning fungal biodiversity and conservation in Malta's National Biodiversity Strategy and Action plan to 2030.

MMA's aim is to educate and train, in collaboration with other mycological societies by holding workshops locally and overseas to further discover the world of fungi and make the local community aware of their importance and impact on the environment. Another part of the project will be to encourage people to grow edible fungi in their homes to control over-collection of edible wild species. Although since the inception of Malta Mycological Association a lot of interest has been generated along with others taking on board the promotion of the importance of fungi, a lot more needs to be done to raise awareness.

\section{How many species of Fungi are there in Malta?}

Studies on fungi in Malta started at the beginning of the $19^{\text {th }}$ century between 1827 and 1831 when Zerapha (Zerafa) published his work the Flora Melitensis Thesaurus and four species of macro fungi were recorded namely: Agaricus campestris, Agaricus ephemerus, Boletus ignarius and Phallus impudicus. Between 1855 and 1890 three books came to the life but Flora Melitensis Nova (Sommier and Caruana Gatto; 1915) may be considered the most extensive one that concentrated on Maltese fungi. Both Sommier and Caruana Gatto are considered the pioneer scientists in the documentation of Maltese fungi where 50 specimens were recorded.

The human population on the island, at the time of Flora Melitensis Nova publication, was 228,534 and no vehicles. Today's population is ranged between 436 to 475,000 and with a large number of vehicles. On a daily basis the local environment is undergoing phenomenal stress with green areas disappearing at a rapid rate due to excessive domestic construction. The islands of Malta and Gozo are predominantly made up of garigue, steppe and maquis, woodland is now scarce and we are now at a very high risk of losing what species we have left on the island. Therefore, apart from Suillus collinitus, Volvopluteus gloiocephalus, Daldinia concentrica, Auricularia auricula-judae, which are very common on the island all other species need to be considered endangered.

Major works were carried out in the $60 \mathrm{~s}, 70 \mathrm{~s}$ and $80 \mathrm{~s}$ by Michael Briffa and Edwin Lanfranco, who scoured the island and have kept extensive records on their finds. To-date their finds total about 330 species (Figs. 3-5).

Michael Briffa one of the island's most honoured naturalists was awarded the Buonamico Award in March 2018 for his environmental work. He has been instrumental in recording and preserving specimens in his fungarium and todate would have the largest collection of fungal species of the island. 
First European record of Coriolopsis aspera (Jungh) Teng (Polyporaceae) from Malta was published by Briffa (2002a) after being examined at Oslo University. It has been contemplated that it can either be an introduced species or a rare native one.

In 2015 Loizides et al. introduced a new species to the science from Malta and Cyprus as Geoglossum dunense Loizides, M. Carbone \& P. Alvarado.

A new record of Morel (Morchella galilaea) was collected and described by Mifsud in 2016 and for the first time for the island of Gozo.

So far, recent official published works on mycology have mainly been done by Briffa and Lanfranco (1986), Briffa (2001 and 2002a,b), Lanfranco (1954 - 2013), Mifsud (2011-2012), Sammut (2011-2012-, 2015, 2016) and Sammut and Melzer (2012, 2013). Work needs to be done to ensure accurate records are kept on finds and collections on the island, therefore the intention is to collect data and have a centralised database where everyone will be able to have access to information, setting a local fungi scene. It is imperative that scientific records are kept along with information and data geared to encourage amateur interest in the field.

To-date a Mycology Faculty or even department does not exist at the University of Malta. There is only a Mycology lab but this mainly deals with pathogens. Intermittent studies and papers have been written on macro fungi, continuous promotion of the importance of these organisms needs to be developed to harness interest on the subject.

In the fifth national report of the Republic of Malta produced by Malta Environment and Planning Authority in 2014 a conservation status of fungi was discussed (https://www.cbd.int/doc/world/mt/mt-nr-05-en.pdf). While the macrofungal mycobiota of the Maltese Islands may amount to some 400 taxa, 18 species of macrofungi are listed in the Red Data Book for the Maltese Islands (Lanfranco 1989). A list of such species is provided below, with the scientific names updated on the basis of Lanfranco (2001) as cited in fifth national report of Republic of Malta. These species are: Daldinia concentrica, Helvella crispa, Sarcosphaera eximia, Agrocybe aegerita, Amanita ovoidea, Amanita verna, Boletus luridus, Boletus pulverulentum, Hygrocybe ovina, Lactarius vinosus, Montagnites arenaria, Phellinus robustus $f$. punicae, Phellinus robustus $f$. amygdali, Pleurotus nebrodensis $f$. minor, Polyporus brumalis, Russula lepida, Tricholomopsis platyphylla, Colus hirudinosus $f$. minor and Tulostoma volvulatum.

In addition, a list of 131 microfungal taxa is included in the same Red List. Such taxa need reassessment as soon as possible. There are still gaps in knowledge in the mycobiota of the Maltese Islands and indeed a sizeable proportion remains unidentified or partially identified and, hence, still unpublished. As noted by Lanfranco (2013) in the country report to the ECFF, major recent contributions on the subject are Briffa \& Lanfranco (1986), Lanfranco (1989), Briffa (2001, 2002a, b) and Sammut \& Melzer (2012). Species with a restricted distribution in Europe include: Sarcosphaera coronaria, Boletopsis grisea, Montagnea candollei, Battarrea phalloides (Falzon, 2004) and Psathyrella bivelata. Other species of restricted European distribution are: Coriolopsis aspera (Briffa 2002a) and Inonotus euphoria, originally recorded as Inonotus indicus (= Aurificaria indica) by Pieri and Rivoire (1996) from material supplied by Briffa. However these two species may possibly have been introduced. Most species recorded are considered to be rare, though in several cases this may be due to under recording.

As far as lichens are concerned, 12 taxa are listed, these being essentially taxa which have been described from the Maltese Islands and which are presumably endemic (Sommier and Caruana Gatto 1915). These species are: Biatora fusco-nigrescens, Caloplaca marmorata var. cephaloidea, Caloplaca melitensis, Caloplaca pyracea var. lactea forma macrocarpa, Collema meliteum var. conglomeratum, Graphina sophistica var. melitense, Lecaniella alocyza var. flavidula, Lecanora sublentigera, Lecidea pertusariicola, Scolicosporium doriae var. decussatum, Thalloedema mammillare var. pulchella and Thalloedema paradoxum. An updated 
checklist of lichens in the Maltese Islands developed by Jennifer Fiorentino (2015), who is a Senior Lecturer in Biology at the University Junior College.

Sarcosphaera coronaria and Boletopsis griseus are legally protected and are covered by the Flora, Fauna and Natural Habitats Protection Regulations (2006) (Legal Notice 311 of 2006, as amended). Two other species: one fungus and one lichen, Pleurotus eryngii var ferulae and Rocella phycopsis respectively are included in Schedule VIII of the afore-cited Regulations; this Schedule lists species whose taking may be subject to management measures. All endemic and possibly endemic species of fungi are legally protected through Regulation 26 of Legal Notice 311 of 2006, as amended. This is of relevance particularly with respect to the many 'possibly endemic' microfungi (which however deserve further taxonomic assessment). Lichens are locally equally unexploited, with only two species having been exploited. These are namely Ramalina durieui and Roccella phycopsis, which were traditionally used in decorating nativity cribs; their utilisation for such activities has nowadays mostly fallen in disuse.

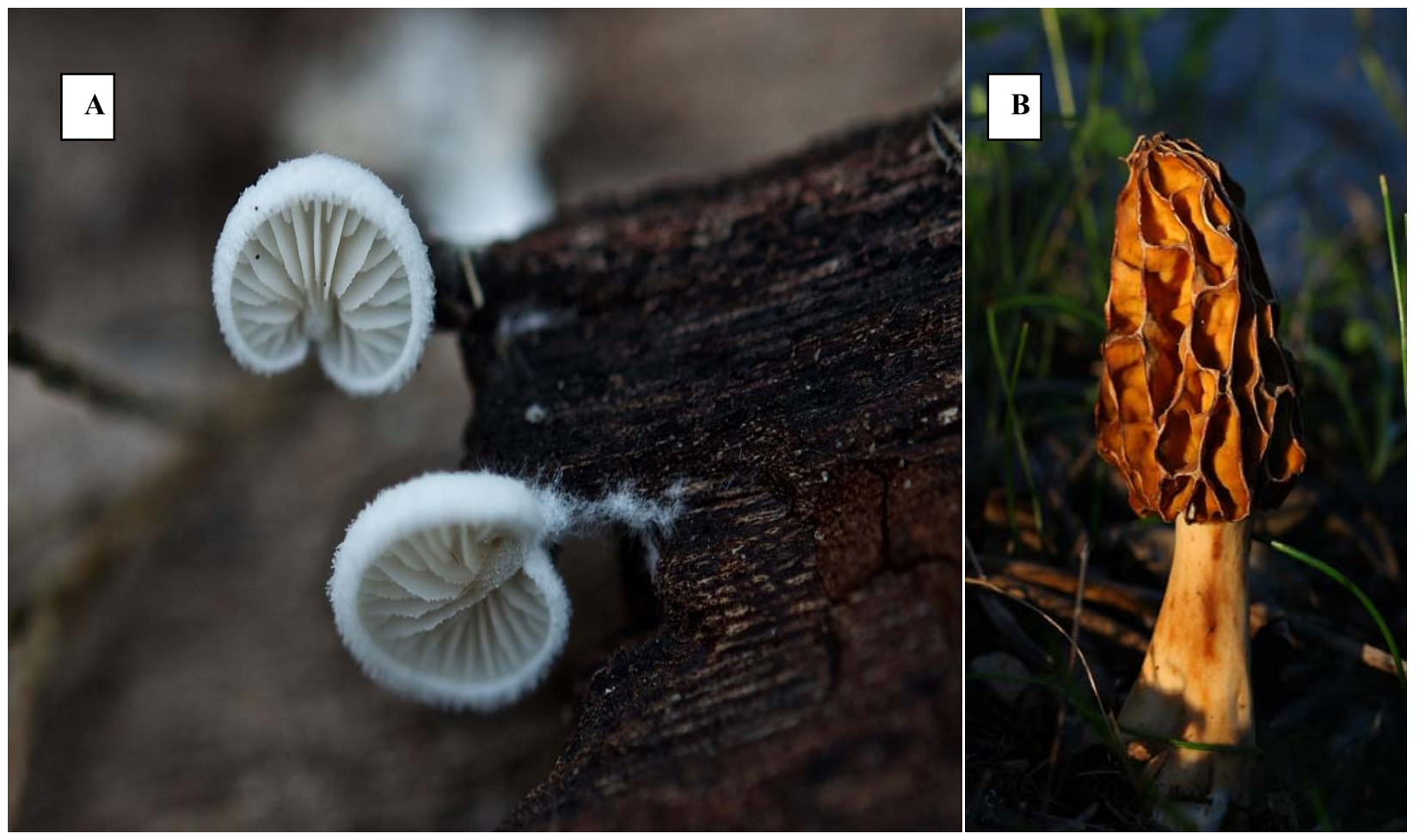

Fig. 3- A- Hemimycena tortuosa (Photo by Marica Lewis), B- Morchella galilaea (Photo by Stephen Mifsud).

The macrofungi recorded in Malta are under extensive revision and updating right now by Lewis and Abdel-Azeem (Unpublished work) against data of index Fungorum (http://www.indexfungorum.org/Names/Names.asp). Their treatment will include Maltese macrofungi which have been distributed among 8 classes, 17 orders, 59 families, 158 genera and 313 species. Maltese macrofungi are divided into two taxonomic groups: (i) Ascomycota: 4 classes, 4 orders, 11 families, 25 genera, 37 species, and (ii) Basidiomycota: 4 classes, 13 orders, 48 families, 133 genera, 276 species identified. Out of theses taxa, Lewis and Abdel-Azeem found 17 taxa need more revision concerning their nomenclature as they have been recorded by wrong names. Taxa with uncertain position (Incertae sedis) were distributed among classes, orders and families.

Checklists are important tools in taxonomy, systematics and conservation (Söderström et al. 2007, 2008; Moustafa and Abdel-Azeem 2011; Abdel-Azeem and Salem 2013; Nafady et al. 
2016). In spite of that, several important areas lack recent checklists, including Malta. This proposed work of Lewis and Abdel-Azeem will close the gaps in knowledge on the fungi diversity of Malta by providing a comprehensive checklist of Maltese fungi provided with a dichotomous key of all recorded taxa.

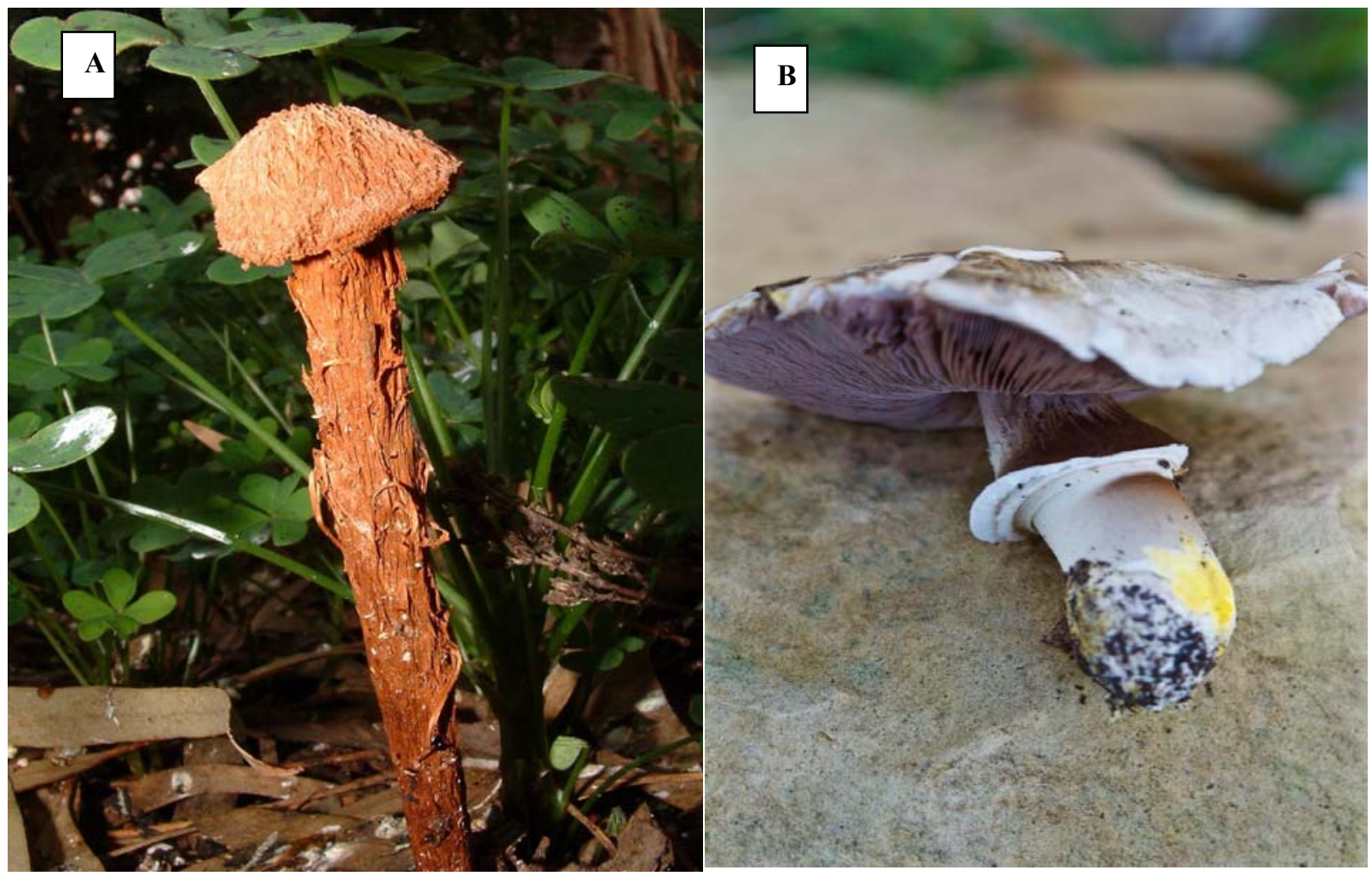

Fig. 4- A- Battarrea phalloides (Photo by Victor Falzon), B- Agaricus iodosmus (Photo by

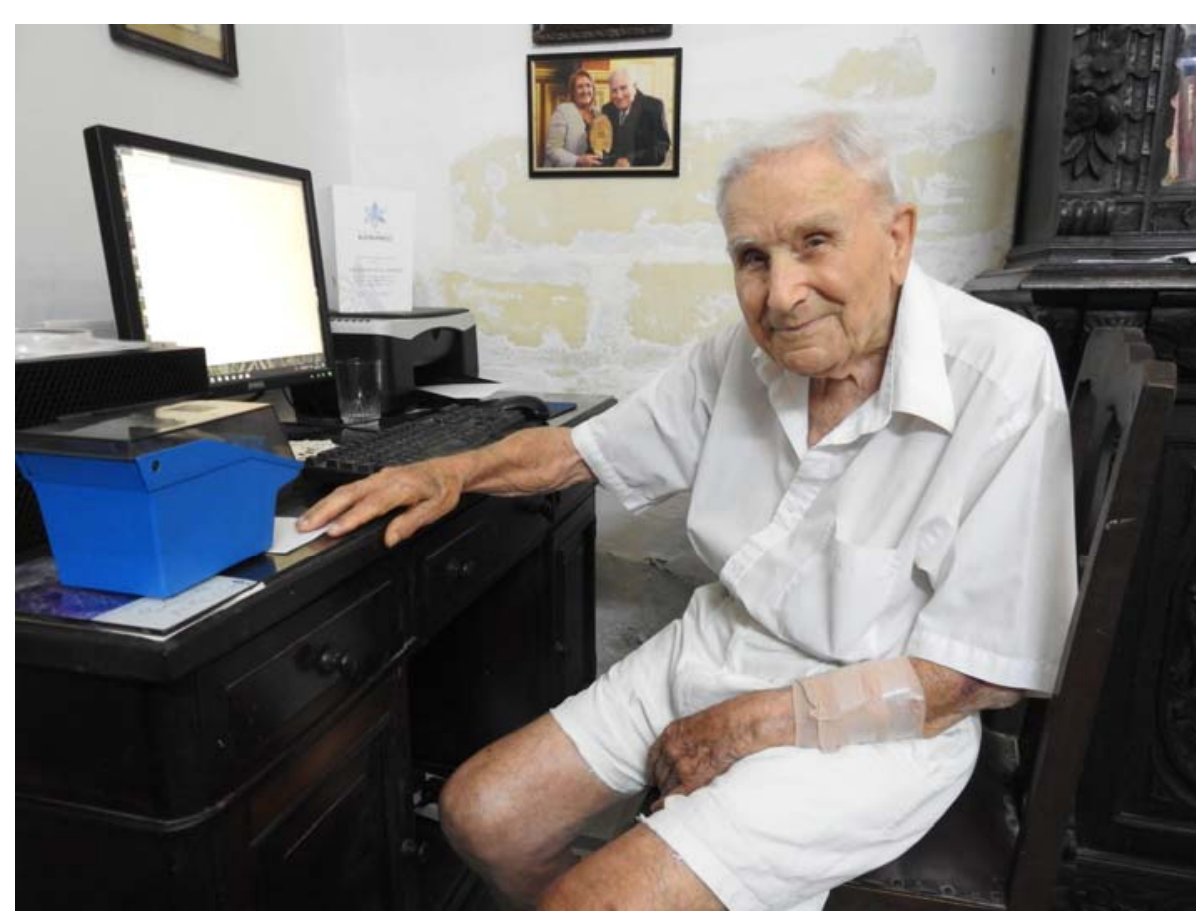

Marica Lewis).

Fig. 5- Michael Briffa (Photo by Marica Lewis). 


\section{Conclusion}

As the population on the islands of Malta and Gozo continues to grow, the need for development increases, the continuous assault on the environment is having a detrimental effect on the near future of macrofungal diversity which along with other environmental areas is seriously threatened. Although some effort has been made in writing papers on the subject by literally a handful of people, albeit intermittently, having the subject as part of the educational curriculum, is imperative, along with campaigning, increasing awareness with current politicians and persevering on a local level and as an international team. From the Malta point of view, a lot of work needs to be done and it is hoped that in collaboration with the Arab Society for Fungal Conservation and other international societies, we would be in a position to achieve this, through networking, sharing information and promoting awareness.

\section{Acknowledgments}

I would like to thank all authors of all literatures used in this work with special thanks to Michael Briffa and Edwin Lanfranco. All gratitude goes to Dr. Ahmed Abdel-Azeem (Botany Department, Faculty of Science, University of Suez Canal) for his patience, altruism and generosity with sharing his knowledge, exceptional encouragement and guidance.

\section{References}

Abdel-Azeem A.M. and Salem F.M. 2013. A checklist of Egyptian fungi: I. Protozoan fungal analogues, Mycosphere, 4(4): 794-807, DOI 10.5943/mycosphere/4/4/15.

Abdel-Azeem, A.M. and Salem, F.M. 2017. The orphans of Rio in Northern Africa Egypt, a case study. Sustainability Cybernetics Journal, 2(1): 1-16.

Briffa M. 2001. Polypores recorded in Malta: additions and updated checklist. The Central Mediterranean Naturalist, 3 (3): 124-129.

Briffa M. 2002a. First European record of Coriolopsis aspera (Jungh) Teng (Polyporaceae) from Malta. Mycologists, 16: 187. DOI: 10.1017/S0269915X02004020

Briffa M. 2002b. Some additions to the macrofungi of Malta. The Central Mediterranean Naturalist, 1 (4): 197-202.

Briffa M. and Lanfranco E 1986. The Macrofungi of the Maltese Islands: additions and notes. The Central Mediterranean Naturalist; 1 (4): 69-79

Ezilon Maps. Available from: https://www.ezilon.com/maps/europe/malta-physical-maps.html. (accessed 17 August 2018).

Fiorentino J. 2015. Clarification regarding old records of Roccella in the Maltese Islands. Mycosphere, 6(6): 673-680.

Flora, Fauna and Natural Habitats Protection Regulations. 2006. Available from: https://www.gov.mt/en/Government/DOI/Pages/Department-of-Information.aspx (accessed 17 August 2018).

Index Fungorum database. Available from: http://www.indexfungorum.org/names/Names.asp (accessed 7 July 2018).

Lanfranco E. 1968. Some Cryptogams met with during recent excursions. Natural history Society of Malta and Malta Ornithological Society, Report for 1967: 7- 12 (mimeographed). Malta.

Lanfranco E. 1972. Mushrooms in Malta - new records. Maltese Natura List, 1 (3): 25 - $28+1$ plate. Natural History Society of Malta (mimeographed).

Lanfranco E. 1979. Colus hirudinosus. Potamon, 2: 13. Society for the Study and Conservation of Nature, Malta (mimeographed).

Lanfranco E. 1984a. The vegetation of the Mediterranean area (mimeographed lecture notes). The University of Malta. 15pp. 
Lanfranco E. 1984b. Society for the Study and Conservation of Nature: excursion notes for 2.12.1984. Malta (mimeographed).

Lanfranco E. 1984c. Mushrooms and other fungi in the Maltese Islands. Handout for public lecture, 3pp. (mimeographed). Society for the Study and Conservation of Nature. Malta.

Lanfranco E. 1984d. Mushrooms and other fungi in the Maltese Islands. Handout for public lecture, 3pp. (mimeographed). Society for the Study and Conservation of Nature. Malta.

Lanfranco, E. 1989. The flora. In: Schembri, P.J. \& Sultana, J. [eds] Red data book for the Maltese Islands. pp. 5-70; Valletta, Malta: Department of Information.

Lanfranco G. 1954. Rare Fungi in Malta. Times of Malta: 20 July 1954. Progress Press, Malta.

Lanfranco G. 1958. Pjanti ta' Malta Ftit Magnrufa. pronostku MaLti, 127 - 134.

Lanfranco G. 1959. Il-Fungi ta I Malta. IL-Kewkba, 5 (1): 2 - 3. De La Salle College, Cottonera, Malta.

Lanfranco G. 1961. Il-Fungi ta' Malta. Tajjeb Li Tkun Taf: 3/61, 27 February 1961. Department of Information, Malta.

Loizides M., Carbone M.D. and Alvarado P. 2015. Geoglossum dunense (Ascomycota, Geoglossales): a new species from the Mediterranean islands of Cyprus and Malta. Mycological Progress, 14: 1-8.

Malta Mycological Association. Available from: https://www.facebook.com/mycomalta/ (accessed 17 August 2018).

Mifsud S. 2011-201. Marasiums corbariensis (Roum.) Singer (family Marasmiaceae Roze ex Kuhner) a new fungal species for Malta. The Central Mediterranean Naturalist; 5: 5253.

Moustafa A.F. and Abdel-Azeem A.M. 2011. An annotated check-list of Ascomycota reported from soil and other terricolous substrates in Egypt. J. Basic Appl. Mycol. 2: 1-27.

Nafady N., Abdel-Azeem A.M. and Salem, F.M., 2016. A checklist of Egyptian fungi: II. Glomeromycota. Microbial Biosystems, 1, 40-49.

New Species of Fungi. Available from: http://gozonews.com/67444/ecogozo-discoverscompletely-new-species-of-fungi-from-gozo/(accessed 17 August 2018).

Pieri M. and Rivoire B. 1996. A propos de quelques Polypores rare ou critiques recoltes recemment. Bull. Soc. Mycol. France t.112: 163-187.

Sammut C. 2011-2012. Pithya cupressina: A new addition to the Maltese mycobiota, The Central Mediterranean Naturalist 5(3 \& 4): 54

Sammut C. 2015. Additions to the Mycobiota of the Maltese Islands: Pezizomycotina. First Part. Micol. Veget. Medit., 30 (2): 75-96.

Sammut C. 2016. Additions to the Mycobiota of the Maltese Islands: Pezizomycotina. Second Part. Micol. Veget. Medit., 31 (1): 3-44. 2016

Sammut C. and Melzer A. 2012. Psathyrellaceae from Malta, a preliminary survey. Veget. Medit., 27 (1): 33-44. 2012

Sammut C. and Melzer A. 2013. Conocybe from Malta. Micol. Veget. Medit., 28 (2): 127-134.

Schembri P. J. and Sultana J. 1989. Red data book for the Maltese Islands. Malta: Department of Information, pp. 163.

Söderström L., Hagborg A., von Konrat M. and Renner M.A.M. 2008. Early Land Plants Today: Liverwort checklist of checklists. Fieldiana, Botany, n.s. 47, 105-130.

Söderström L., Urmi E. and Váňa J. 2007. The distribution of Hepaticae and Anthocerotae in Europe and Macaronesia- Update 1-427. Cryptogamie, Bryologie 28, 299-350.

Sommier S. and Caruana Gatto A. 1915. Flora Melitensis Nova, Firenze, Italy. 502 pp

The fifth national report of Republic of Malta 2014. Available from: https://www.cbd.int/doc/world/mt/mt-nr-05-en.pdf (accessed 17 August 2018). 
Times of Malta. Available from: www.timesofmalta.com/articles/view/20180710/local/increasein-malta-population-more-than-15-times-that-of-the-eu. (accessed 17 August 2018).

Zerapha S. 1827-1831. Florae Melitensis Thesaurus, sive planatarum enumeratio quae in Melite Gaulosque insulis aut indigenae aut vulgatissimae. Malta, 86pp 